Article

\title{
Thermal Stability and Kinetics of Formation of Magnesium Oxychloride Phase $3 \mathrm{Mg}(\mathrm{OH})_{2} \cdot \mathrm{MgCl}_{2} \cdot 8 \mathrm{H}_{2} \mathrm{O}$
}

\author{
Michal Lojka ${ }^{1}$, Ondřej Jankovský ${ }^{1}$, Adéla Jiř̌čková ${ }^{1}$, Anna-Marie Lauermannová ${ }^{1}$, \\ Filip Antončík ${ }^{1}$, David Sedmidubský ${ }^{1}{ }^{1}$, Zbyšek Pavlík ${ }^{2}$ () and Milena Pavlíková ${ }^{2, *}$ \\ 1 Department of Inorganic Chemistry, Faculty of Chemical Technology, University of Chemistry and \\ Technology, Technická 5, 16628 Prague 6, Czech Republic; michal.lojka@vscht.cz (M.L.); \\ ondrej.jankovsky@vscht.cz (O.J.); adela.jirickova@vscht.cz (A.J.); lauermaa@vscht.cz (A.-M.L.); \\ filip.antoncik@vscht.cz (F.A.); david.sedmidubsky@vscht.cz (D.S.) \\ 2 Department of Materials Engineering and Chemistry, Faculty of Civil Engineering, Czech Technical \\ University in Prague, Thákurova 7, 16629 Prague 6, Czech Republic; pavlikz@fsv.cvut.cz \\ * Correspondence: milena.pavlikova@fsv.cvut.cz; Tel.: +420-224354688
}

Received: 16 January 2020; Accepted: 6 February 2020; Published: 7 February 2020

\begin{abstract}
In this paper, magnesium oxychloride cement with stoichiometry $3 \mathrm{Mg}(\mathrm{OH})_{2} \cdot \mathrm{MgCl}_{2} \cdot 8 \mathrm{H}_{2} \mathrm{O}$ (MOC 3-1-8) was prepared and characterized. The phase composition and kinetics of formation were studied by X-ray diffraction (XRD) and Rietveld analysis of obtained diffractograms. The chemical composition was analyzed using X-ray fluorescence (XRF) and energy dispersive spectroscopy (EDS). Furthermore, scanning electron microscopy (SEM) was used to study morphology, and Fourier Transform Infrared (FT-IR) spectroscopy was also used for the analysis of the prepared sample. In addition, thermal stability was tested using simultaneous thermal analysis (STA) combined with mass spectroscopy (MS). The obtained data gave evidence of the fast formation of MOC 3-1-8, which started to precipitate rapidly. As the length of the time of ripening increased, the amount of $\mathrm{MgO}$ decreased, while the amount of MOC 3-1-8 increased. The fast formation of the MOC 3-1-8 phase at an ambient temperature is important for its application in the production of low-energy construction materials, which corresponds with the challenges of a sustainable building industry.
\end{abstract}

Keywords: magnesium oxychloride cement; non-hydraulic binder; MOC phases; kinetics of formation; thermal stability

\section{Introduction}

In the past few decades, Portland cement (PC) has become a dominant material in the construction industry, putting other materials aside. These materials were historically and locally used in consideration of traditions, local conditions, and specific fields of application. It changed after the discovery of PC in the 19th century and after its expansion over the last sixty years. Nowadays, cement is the most consumed material for construction development around the world. The current cement consumption is about 4.6 billion tons annually [1,2]. Unfortunately, the production of cement is associated with an adverse environmental impact and is responsible for approximately $7 \%$ of the total anthropogenic $\mathrm{CO}_{2}$ emissions [3]. Moreover, cement manufacturing requires a high amount of energy for clinkering ( $12 \%$ to $15 \%$ of industrial energy consumption [4]) and depletes natural resources due to the consumption of large quantities of raw materials, such as high-grade limestone and clays [5]. Therefore, taking into account the environmental sustainability issues, there is a big tendency to rediscover low-energy materials that are not widely used and have been set aside because of PC. Magnesium carbonate and reactive magnesia cements can be put into this group of 
materials [6-10]. Magnesia-based cements represent potentially $\mathrm{CO}_{2}$-negative materials, and, also, they can be considered eco-friendly. They have been used in practice for more than 150 years.

Magnesium oxychloride cement (MOC) is a type of non-hydraulic binder that is obtained by mixing $\mathrm{MgO}$ powder with the aqueous solution of magnesium dichloride. This process does not require humid curing [11]. MOC was discovered by Sorel in 1867 [12]. The reaction between $\mathrm{MgO}$ and $\mathrm{MgCl}_{2}$ provides a gel-like product that hardens after a specific curing time (depending on the content of different MOC phases) [13]. The magnesium oxide used in this reaction is obtained by the calcination of magnesite $\left(\mathrm{MgCO}_{3}\right)$, usually at $750{ }^{\circ} \mathrm{C}$. One of the advantages of $\mathrm{MOC}$ is that $\mathrm{MgO}$ requires a lower calcination temperature than the $\mathrm{MgO}$ used for $\mathrm{PC}$. This causes a decrease in the use of energy [14]. Although the use of MgO-rich limestone for the production of PC is rare [15], it has been reported that $\mathrm{MgO}$ could lower the melting temperature, increase the quantity of the liquid phase, and change the crystal structure of the mineral phases $[16,17]$.

The cured product, based the on the reaction of $\mathrm{MgO}$ and $\mathrm{MgCl}_{2}$ solution, can be described as a $\mathrm{MgO}-\mathrm{MgCl}_{2}-\mathrm{H}_{2} \mathrm{O}$ system. Depending on the molar ratio of the three parts of this system, possible products can be "Phase 3" $\left(3 \mathrm{Mg}(\mathrm{OH})_{2} \cdot \mathrm{MgCl}_{2} \cdot 8 \mathrm{H}_{2} \mathrm{O}\right)$ and "Phase 5" $\left(5 \mathrm{Mg}(\mathrm{OH})_{2} \cdot \mathrm{MgCl}_{2} \cdot 8 \mathrm{H}_{2} \mathrm{O}\right)$, or "Phase 2" $\left(2 \mathrm{Mg}(\mathrm{OH})_{2} \cdot \mathrm{MgCl}_{2} \cdot 4 \mathrm{H}_{2} \mathrm{O}\right)$ and "Phase 9" $\left(9 \mathrm{Mg}(\mathrm{OH})_{2} \cdot \mathrm{MgCl}_{2} \cdot 5 \mathrm{H}_{2} \mathrm{O}\right)$. The presence of these phases is limited by temperature. Phase 5 and Phase 3 are present at an ambient temperature, while Phase 2 and Phase 9 are present at elevated temperatures (above $100^{\circ} \mathrm{C}$ ) only $[18,19]$. The microstructure of these reaction products shows well-crystallized materials. The crystallized needles can be described as scroll-tubular whiskers. Additional bonding of the whiskers is a major source of the mechanical strength of MOC [20]. All phases of MOC occur as well-crystallized needles that interlock in a rapid growth. If the growth is inhibited by a lack of space, crystals intergrow into a denser structure [21].

MOC has superior properties in comparison to PC. It has sufficient fire resistance [22], low thermal conductivity (comparable to PC) [23], and good resistance to abrasion [24]. An important superior property of MOC is its bonding ability, as it contributes to its high compressive strength (approximately twice as high compared to PC) [25]. Furthermore, MOC is suitable for the incorporation of organic and inorganic aggregates. This property makes it appropriate in the fixation of sewage sludge and in the solidification of municipal solid waste [26].

MOC appears stone-like and can be used in flooring [27], fire protection [28], as a material for grinding wheels [29], or as artificial ivory [30]. The curing time is much shorter than the curing time of PC, so it can be used for quick provisional repairs. [31]. Due to its external appearance, it can be used in insulation panels of rendered walls, in stuccos with revealed aggregates, and for decorative purposes-for example, in light-weight composite products with wood to create wood-like materials with better mechanical properties. The material has lower alkalinity ( $\mathrm{pH}$ of 10-11) in comparison to ordinary cement ( $\mathrm{pH}$ of 12-13). This property makes it suitable for usage in composites with glass fibers [32]. When used in the solidification and stabilization of sewage sludge, $\mathrm{MgO}$ and $\mathrm{MgCl}_{2}$ rapidly harden in a reaction with the water contained in the sludge and create a solid system containing two reaction phases-Phase 5 and Phase 3. During this process, a net structure is created on the condition of complete hydration [33].

Unfortunately, MOC has poor water resistance when exposed to an excessive amount of moisture, particularly at high temperatures [34]. This property can be affected by the use of various additives and a specific course of curing. These influences have already been intensively studied by Sglavo et al. [35], Xu et al. [24], and Liu et al. [36]. Chen et al. improved the water resistance through the use of tartaric acid or phosphoric acid [37]. Reaction products can also transform into magnesium carbonate-chloride due to the continuous exposure to air [38].

According to the literature, MOC 5-1-8 showed better mechanical properties in comparison to MOC 3-1-8. From a thermodynamic point of view, the coexistence of $\mathrm{MgO}$ and $\mathrm{MOC} 3-1-8$ as composites is not possible [39]. On the other hand, composites containing $\mathrm{MgO}$ and MOC 5-1-8 have been intensively studied. In our contribution, we focused on phase MOC 3-1-8 in order to understand the kinetics of formation and the thermal performance of this phase, which is essential to understanding 
the whole $\mathrm{MgO}-\mathrm{MgCl}_{2}-\mathrm{H}_{2} \mathrm{O}$ system. The kinetics of the formation of the MOC 3-1-8 phase is the crucial parameter for MOC use in the production of alternative, low-energy building materials and research of MOC-modified binders. The quantification of the phases was thoroughly investigated using Rietveld analysis. The thermal stability of the MOC 3-1-8 phase was also investigated in order to obtain information on structural changes that the tested material underwent at high temperatures.

\section{Materials and Methods}

The following chemicals were used for the mixing of MOC: $\mathrm{MgCl}_{2} \cdot 6 \mathrm{H}_{2} \mathrm{O}(>99 \%$, Penta, Chrudim, Czech Republic); and $\mathrm{MgO}$ (>98\%, Penta, Chrudim, Czech Republic). Deionized water (16.8 M $\Omega$ ) was used for all syntheses. For the synthesis of the stoichiometric phase, the ratio $3 \mathrm{MgO}$ to $\mathrm{MgCl}_{2} \cdot 6 \mathrm{H}_{2} \mathrm{O}$ to $5 \mathrm{H}_{2} \mathrm{O}$ was used for the synthesis of MOC with the composition $3 \mathrm{Mg}(\mathrm{OH})_{2} \cdot \mathrm{MgCl}_{2} \cdot 8 \mathrm{H}_{2} \mathrm{O}$ (known as Phase 3, MOC 3-1-8, or also as $\left.\mathrm{Mg}_{2}(\mathrm{OH})_{3} \mathrm{Cl} \cdot 4 \mathrm{H}_{2} \mathrm{O}\right)$. The samples were termed MOC 3-1-8, accordingly. For the experiment, we dissolved $19.54 \mathrm{~g}$ of $\mathrm{MgCl}_{2} \cdot 6 \mathrm{H}_{2} \mathrm{O}$ in $8.66 \mathrm{~g}$ of deionized water. In the next step, $11.62 \mathrm{~g}$ of magnesium oxide was added, and the suspension was intensively stirred for five minutes. One part of the suspension was then applied on the X-ray diffraction (XRD) holder (specimen holder rings PMMA, for D2 and D8, $8.5 \mathrm{~mm}$ high, sample reception $\varnothing 25 \mathrm{~mm}$ ), and the rest of the suspension was placed into a plastic beaker for other analyses.

The formation of magnesium oxychloride cement MOC 3-1-8 is summarized in the following equation:

$$
3 \mathrm{MgO}+\mathrm{MgCl}_{2} \cdot 6 \mathrm{H}_{2} \mathrm{O}+5 \mathrm{H}_{2} \mathrm{O} \rightarrow 3 \mathrm{Mg}(\mathrm{OH})_{2} \cdot \mathrm{MgCl}_{2} \cdot 8 \mathrm{H}_{2} \mathrm{O}
$$

First, the raw materials were analyzed. The chemical and phase composition of commercially delivered $\mathrm{MgO}$ and $\mathrm{MgCl}_{2} \cdot 6 \mathrm{H}_{2} \mathrm{O}$ were tested using X-ray fluorescence (XRF) and X-ray diffraction (XRD) analyses. The details of the applied test methods and used apparatuses are introduced together with a description of the MOC tests below. According to XRF, the $\mathrm{MgO}$ content was $99.7 \mathrm{wt} . \%$, and the starting material contained only traces of calcium. In the case of $\mathrm{MgCl}_{2} \cdot 6 \mathrm{H}_{2} \mathrm{O}$, no significant impurities were detected. The purity was over $99.9 \mathrm{wt} . \%$. Starting materials were also analyzed using X-ray diffraction, where only MgO (JCPDS 04-009-5447) and $\mathrm{MgCl}_{2} \cdot 6 \mathrm{H}_{2} \mathrm{O}$ (JCPDS 01 076-0789) were detected. XRD also confirmed the high purity of both starting materials: no impurities were detected. Diffractograms of $\mathrm{MgO}$ and $\mathrm{MgCl}_{2} \cdot 6 \mathrm{H} 2 \mathrm{O}$ are shown in Figure $\mathrm{S} 1$ of Supplementary Materials.

In addition, for $\mathrm{MgO}$ powder, the Brunauer-Emmett-Teller (BET) surface area and particle size distribution were measured. The BET specific surface area was measured using a NOVAtouch $\mathrm{LX}^{2}$ sorption analyzer (Quantachrome Instruments, Boynton Beach, FL, USA). The sample was outgassed for $10 \mathrm{~h}$ at $100{ }^{\circ} \mathrm{C}$ under high vacuum. A nitrogen-cooled $(77 \mathrm{~K})$ detector was used for the evaluation of the results, using BET and Kelvin equations. The dry and degassed sample's mass was $243 \mathrm{mg}$, and it used an 11-point BET measurement to obtain a more accurate isotherm. The Quantachrome software (TouchWin, Boynton Beach, FL, USA) was used for the evaluation of the measured data and to recalculate the measured value to $\mathrm{m}^{2}$ per $1 \mathrm{~g}$ of the tested sample. The obtained data are graphed in Figure 1. 

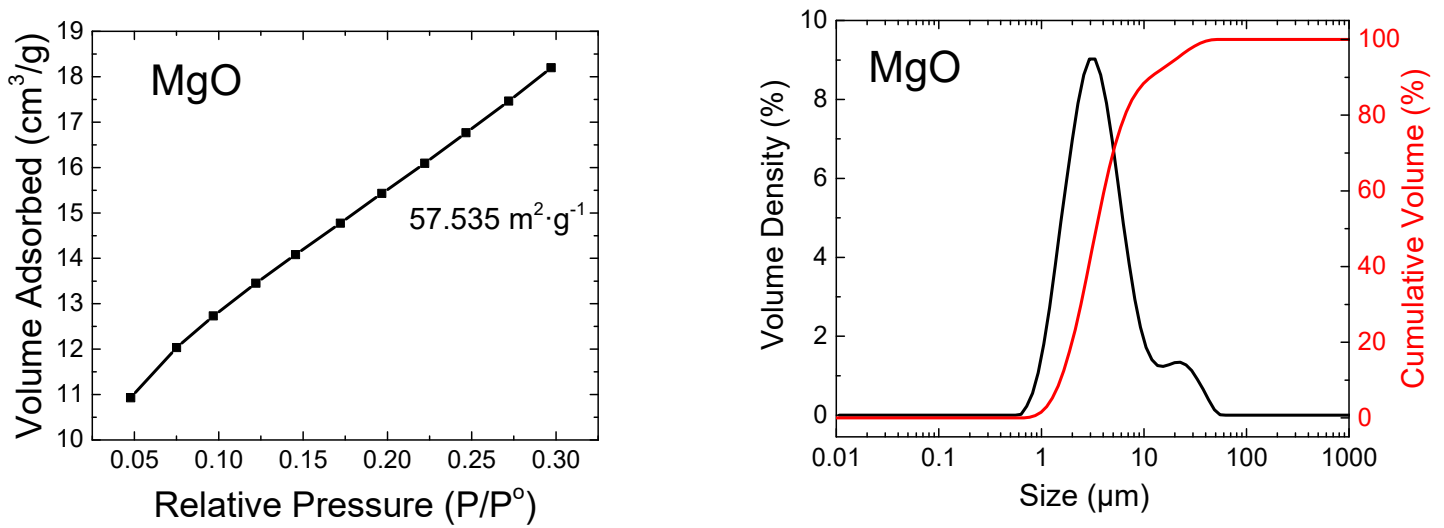

Figure 1. Brunauer-Emmett-Teller (BET) surface area of $\mathrm{MgO}$ powder (left) and particle size distribution of $\mathrm{MgO}$ cumulative and distribution curves (right).

The particle size distribution of commercially delivered $\mathrm{MgO}$ was analyzed by the laser diffraction method using a Malvern Panalytical Mastersizer 3000 device (Malvern Panalytical, Malvern, UK) with a $4 \mathrm{~mW}$ He-Ne $632.8 \mathrm{~nm}$ Red light source and a $10 \mathrm{~mW}$ light-emitting diode (LED) $470 \mathrm{~nm}$ Blue light source. The range of measurement was set from 0.01 to $1000 \mu \mathrm{m}$. The measurement was carried out in a wet cell using Isopropyl Alcohol (Penta, Chrudim, Czech Republic, purity p.a.). During the measurement, a constant mixing of suspension (3000 rpm) was set. The $\mathrm{MgO}$ was measured five times (five scans) and the particle size distribution was determined from the average values (see Figure 1).

The MOC 3-1-8 phase was analyzed using XRD, XRF, energy dispersive spectroscopy (EDS), scanning electron microscopy (SEM), and simultaneous thermal analysis-mass spectroscopy (STA-MS) methods. XRD was performed by a Bruker D2 Phaser powder diffractometer (Bruker AXS GmbH, Karlsruhe, Germany) with Bragg-Brentano geometry, applying $\mathrm{CuK} \alpha$ radiation $(\lambda=0.15418 \mathrm{~nm}$, $\mathrm{U}=30 \mathrm{kV}, \mathrm{I}=10 \mathrm{~mA}$ ) and a rotation (five rounds per minute). The step size was set to $0.02^{\circ}(2 \theta)$ and the overall data were obtained from the angular range of $5^{\circ}-80^{\circ}$. To determine the kinetics of the formation of Phase 3, the sample was analyzed every $12 \mathrm{~h}$ for 7 days. X'Pert HighScore Plus software version 4.0 (PANalytical, Almelo, Netherlands) was applied to evaluate the obtained set of data.

The chemical composition of the sample was determined by XRF using an Axios sequential WD (Wavelength Dispersive)-XRF spectrometer (PANalytical, Almelo, The Netherlands) equipped with an $\mathrm{Rh}$ anode end-window $\mathrm{X}$-ray tube fitted with a $50 \mu \mathrm{m}$ beryllium window. The software SuperQ 5 (PANalytical) was used to collect the measured data. The sample was pressed (with no binding agents) on a pellet of $\mathrm{H}_{3} \mathrm{BO}_{3}$, where the total thickness was $\sim 5 \mathrm{~mm}$ and the diameter was $40 \mathrm{~mm}$.

SEM was used in order to study the morphology (Tescan MAIA 3, TESCAN Brno, s.r.o., Brno, Czech Republic). Using an EDS analyzer (X-Max150, Oxford instruments, High Wycombe, UK) with a $20 \mathrm{~mm}^{2}$ silicon drift detector (Oxford instruments, High Wycombe, UK) and AZtecEnergy software (Oxford Instruments), we determined the elemental composition and mapping. Five scans were performed with an overall measuring time of $10 \mathrm{~min}$ to obtain the average elemental composition. The samples were set on a conductive tape (made of carbon) to establish the conductivity of the measurements. Gold sputtering $(5 \mathrm{~nm})$ was used before the measurement. The electron beam for both SEM and SEM-EDS analysis was set to $10 \mathrm{kV}$, with the working distance $10 \mathrm{~mm}$.

To identify the chemical environments of the inorganic bonds within the hardened MOC samples, FT-IR (Fourier Transform Infrared) spectroscopy was used. Mid-infrared spectra were analyzed on a Nicolet 6700 spectrometer (Thermo Fisher Scientific), using the ATR (attenuated total reflectance) technique after 32 scans, with wavenumbers ranging from $4000 \mathrm{~cm}^{-1}$ to $400 \mathrm{~cm}^{-1}$ and with a spectral resolution of $4 \mathrm{~cm}^{-1}$. Samples were prepared by homogenization in an agate grinding mortar of the samples after 28 days.

A Setsys Evolution apparatus from Setaram Instrumentation (Caluire, France) was used to carry out STA with a temperature of up to $1000^{\circ} \mathrm{C}$. The measurements were performed in a dynamic helium 
atmosphere, where the flow rate was set to $50 \mathrm{~mL} / \mathrm{min}$ and the heating rate to $10{ }^{\circ} \mathrm{C} / \mathrm{min}$. The gases evolving during heating were analyzed by an OmniStar ${ }^{\mathrm{TM}}$ mass spectrometer from Pffeifer Vacuum (Pffeifer Vacuum GmbH, Aßlar, Germany).

\section{Results and Discussion}

In the first experiment, we tested the kinetics of formation of the phase MOC 3-1-8. XRD diffractograms were acquired every $12 \mathrm{~h}$, as can be seen in Figure 2. At the beginning, only $\mathrm{MgO}$ (JCPDS 01-075-0447) was present in the sample because it is insoluble in water, while magnesium chloride was entirely dissolved. $\mathrm{MgO}$ can be seen at $2 \theta=42.9$ (reflection 400 ) and at $2 \theta=62.2$ (reflection 440). Note that a gray dashed line in Figure 2 shows the positions of these major reflections. Another crystalline phase, MOC 3-1-8, started to precipitate rapidly. After $12 \mathrm{~h}$, the sample already contained 72\% of MOC 3-1-8 (JCPDS 00-007-0412). The strongest reflection (100) for MOC-3-1-8 was found at $2 \theta=11.1$. With the time of ripening increasing, the amount of $\mathrm{MgO}$ decreased, while the amount of MOC 3-1-8 increased. Time dependence of sample's composition is shown in Figure 3. After $36 \mathrm{~h}$, the sample contained $>99 \mathrm{wt}$ \% of MOC 3-1-8. Let us note that the quantification was performed for the purpose of studying the rate reaction of $\mathrm{MgO}$ and the formation of the MOC 3-1-8 phase; hence, only these were considered for the Rietveld refinement.

Due to the environmental and financial reasons associated with the sustainability of the building industry, MOC and other low-energy, alternative materials should partially replace the construction market products based on various kinds of cement. Therefore, as ordinary Portland cement concrete is usually tested after 28 days of curing, we also measured the same MOC sample after 28 days at room temperature. The MOC 3-1-8 was detected; however, a low amount of Magnesium Carbonate Aqua Chloride Hydroxide Hydrate (Chlorartinite: JCPDS 00-061-0391) was observed on the surface $(2 \theta=7.8$. For reflection 110, see Figure 4).

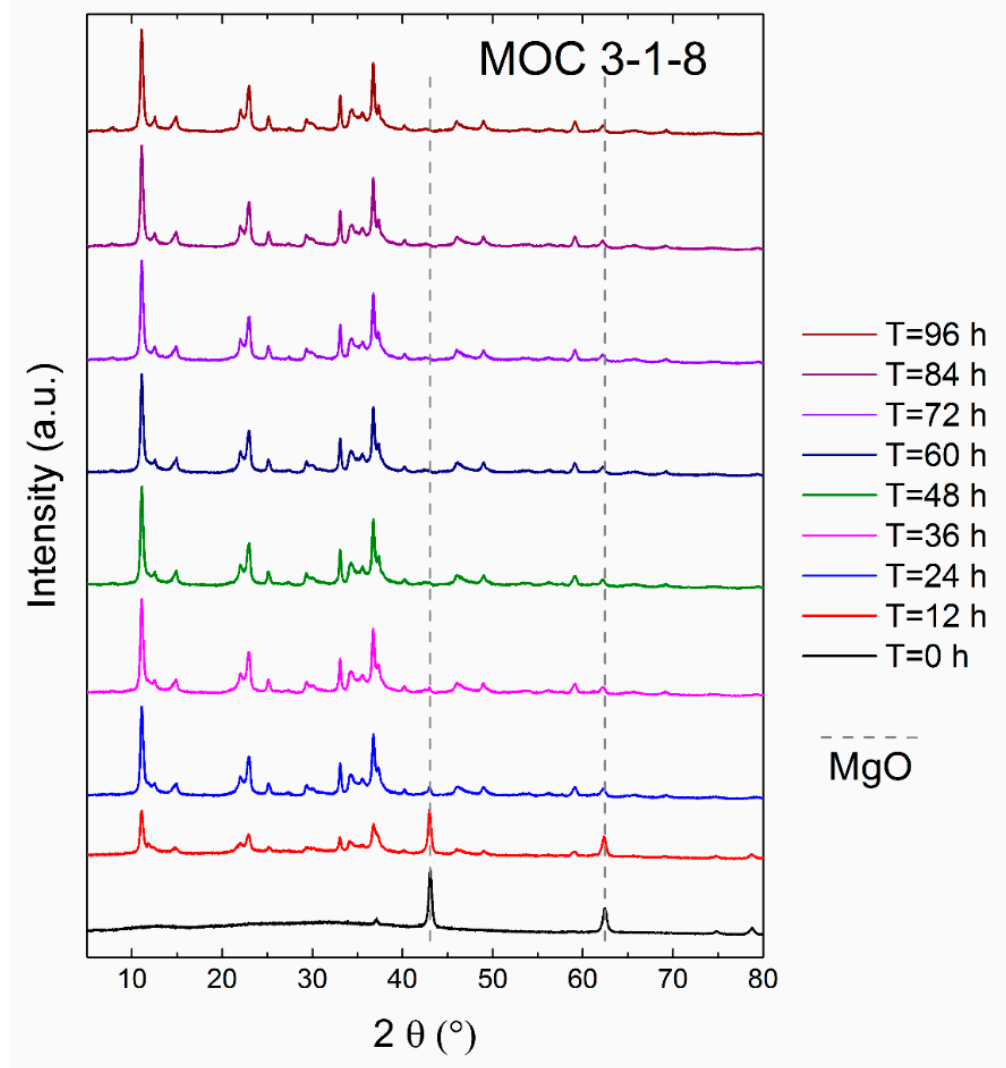

Figure 2. X-ray diffraction patterns of magnesium oxychloride cement (MOC) 3-1-8 suspensions measured for $96 \mathrm{~h}$. 


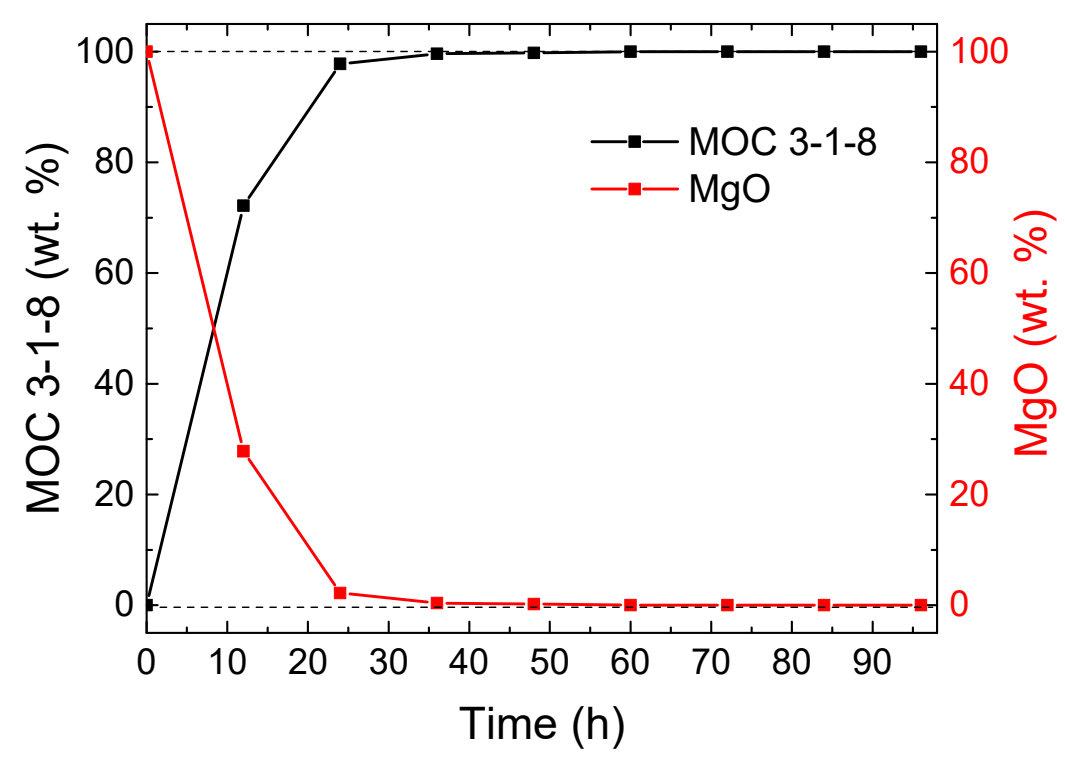

Figure 3. Sample composition obtained by Rietveld analysis.

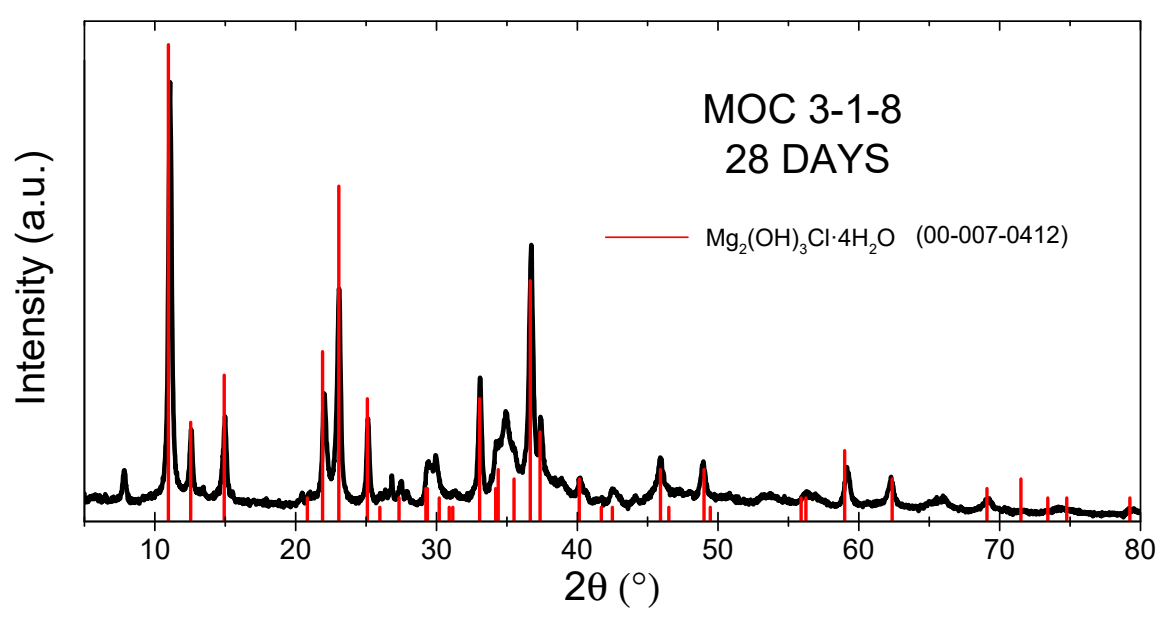

Figure 4. X-ray diffractogram of MOC 3-1-8 after 28 days.

After 28 days, the chemical composition and morphology of the MOC samples were characterized using SEM and EDS. The data are shown in Figure 5. Grains with typical dimensions below $5 \mu \mathrm{m}$ held very well together (interlocking and crosslinked crystalline products of MOC precipitation), which is typical for magnesium oxychloride cements [40]. There were no visible defects within the structure. EDS confirmed high purity, except for magnesium (19.3 wt.\%), oxygen (36.9 wt.\%), and chlorine (30.0 wt.\%). Carbon was detected due to the presence of magnesium carbonate on the surface of the sample, and also from conductive carbon tape. The chemical composition of MOC 3-1-8 was also measured by XRF. The results show that sample MOC 3-1-8 contained $19.8 \mathrm{wt} . \%$ of magnesium, $29.1 \mathrm{wt} . \%$ of chlorine, and $51.0 \mathrm{wt}$ \% of light elements such as C, O, and $\mathrm{H}$ (in the form of water). Sulfur and calcium were detected in very small amounts (lower than $0.05 \mathrm{wt} . \%$ ). 

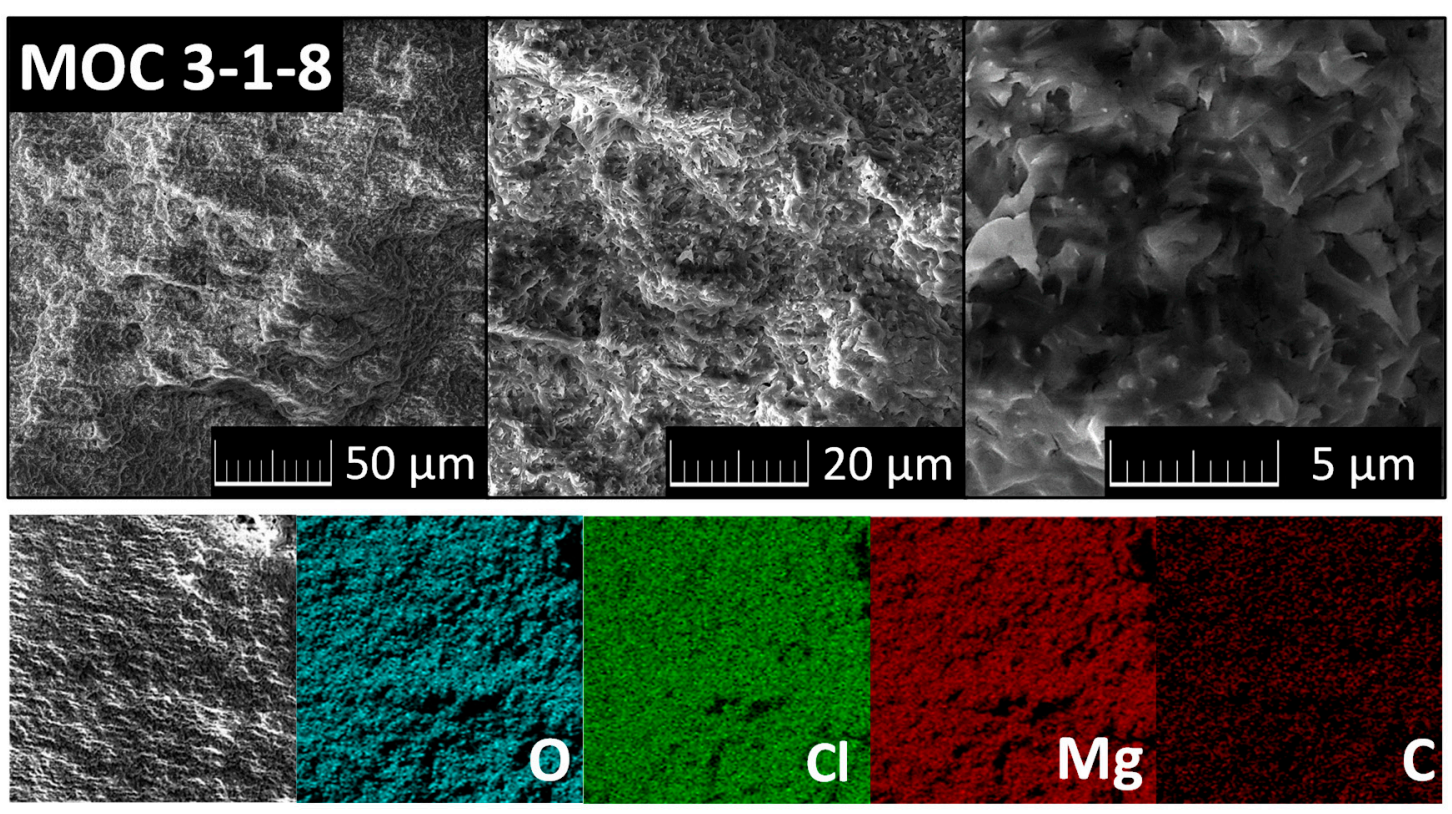

$400 \mu \mathrm{m}$

Figure 5. SEM micrographs and EDS elemental maps of MOC 3-1-8.

The mid-infrared (MIR) spectrum of the MOC 3-1-8 sample is given in Figure 6. It consists of the peaks from the fundamental vibrations of structural $\mathrm{H}_{2} \mathrm{O}$ and the lattice vibrations of $\mathrm{MgCl}_{2}$ and $\mathrm{Mg}(\mathrm{OH})_{2}$ (Table 1). The peaks near $1600 \mathrm{~cm}^{-1}$ are due to the $\mathrm{H}_{2} \mathrm{O}$ bending mode vibration; the peaks in the range of $2000-3700 \mathrm{~cm}^{-1}$ are contributed by the symmetric and asymmetric stretching mode of $\mathrm{O}-\mathrm{H}$ bonds in $\mathrm{H}_{2} \mathrm{O}$ and $\mathrm{Mg}(\mathrm{OH})_{2}$ [41]. The series absorption bands in the range of $1000-400 \mathrm{~cm}^{-1}$ correspond to the existence of lattice translation modes $(\mathrm{Mg}-\mathrm{OH})$ and vibrational modes of the lattice showing the $\mathrm{Mg}-\mathrm{O} / \mathrm{Mg}^{2+}$ and $\mathrm{O} / \mathrm{O}-\mathrm{Mg}-\mathrm{O} / \mathrm{O}-\mathrm{Mg}^{2+}-\mathrm{O}$ bonds [42]. The absorption band at $845 \mathrm{~cm}^{-1}$ was assigned to the characteristic absorption peak of cubic $\mathrm{Mg}-\mathrm{O}$. The lattice vibration modes of $\mathrm{Mg}-\mathrm{O} / \mathrm{Mg}-\mathrm{Cl}$ bonds appear in the absorption spectrum below $500 \mathrm{~cm}^{-1}$, contributed by the vibrations of the bonds of $\mathrm{Mg}-\mathrm{Cl}$ or of $\mathrm{Mg}-\mathrm{O}$.

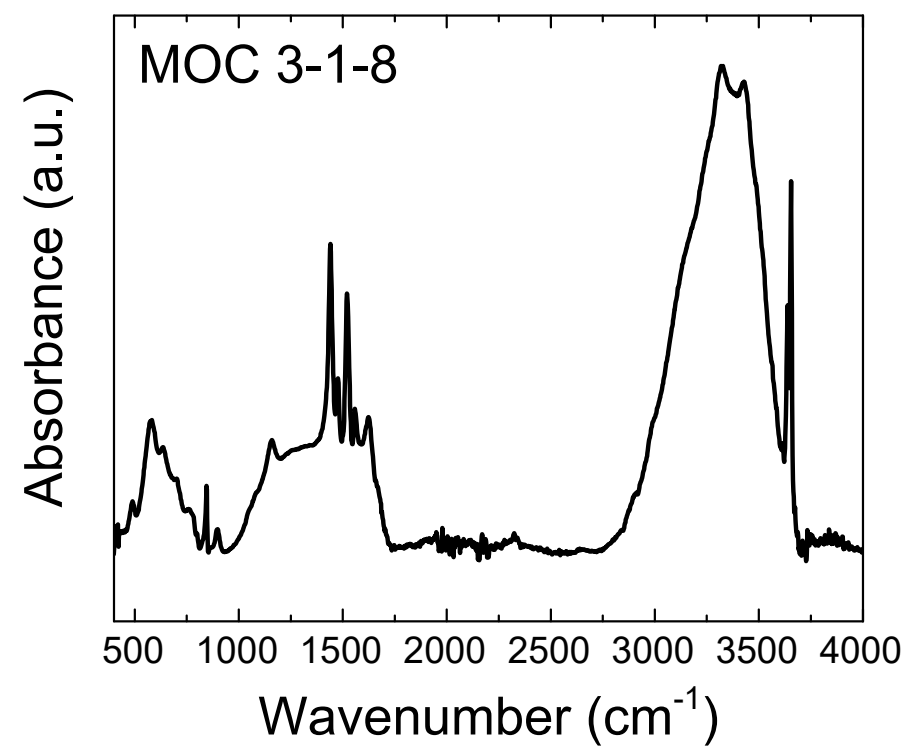

Figure 6. The Mid-IR spectrum of MOC in the range of $400-4000 \mathrm{~cm}^{-1}$. 
Table 1. Assignments of the major absorption bands.

\begin{tabular}{cc}
\hline Wavenumbers $\left(\mathrm{cm}^{-\mathbf{1}}\right)$ & Assignment \\
\hline 3434 & stretching modes $(v)$ of $\mathrm{H}-\mathrm{O}-\mathrm{H}$ in $\mathrm{H}_{2} \mathrm{O}$ \\
3654,3638 & stretching modes $(v)$ of $\mathrm{O}-\mathrm{H}$ in $\mathrm{Mg}(\mathrm{OH})_{2}$ \\
3319 & stretching modes $(v)$ of $\mathrm{H}-\mathrm{O}-\mathrm{H}$ in $\mathrm{H}_{2} \mathrm{O}$ \\
2053 & bending $(\delta)$ and rocking $(\varrho)$ vibrations of $\mathrm{H}-\mathrm{O}-\mathrm{H}_{\text {in }} \mathrm{H}_{2} \mathrm{O}$ \\
1608 & bending $(\delta)$ vibration of $\mathrm{H}-\mathrm{O}-\mathrm{H}$ in $\mathrm{MgCl}_{2} \cdot 8 \mathrm{H}_{2} \mathrm{O}$ \\
stretching modes $(v)$ of $\mathrm{Mg}-\mathrm{O}$ in $\mathrm{MgCl}_{2} \cdot 8 \mathrm{H}_{2} \mathrm{O}$ \\
$1520,1476,1440$ & stretching vibration $(v)$ of the $\mathrm{Mg}-\mathrm{O}$ cubic structure \\
645 & stretching $(v)$ vibrations of $\mathrm{Mg}-\mathrm{O}$ \\
581 & deformation $(\delta)$ and stretching $(v)$ vibrations of $\mathrm{Mg}-\mathrm{Cl}$ \\
489 & translation vibrations of $\mathrm{Mg} / \mathrm{Mg}-\mathrm{O}, \mathrm{Mg}-\mathrm{OH}$ \\
417 & vibrational modes of the lattice showing the $\mathrm{Mg}-\mathrm{O} / \mathrm{Mg}^{2+}$, \\
& O/O-Mg-O/O-Mg $-\mathrm{Mg}-\mathrm{O}$ bonds \\
\hline
\end{tabular}

Thermal stability of MOC 3-1-8 was analyzed using STA-MS (Figure 7). MS signals for water and hydrochloric acid are introduced at the top and differential thermal analysis (DTA) plus thermogravimetry (TG) signals at the bottom of Figure 7. From the data, it is obvious that after the thermal treatment, $\mathrm{MgO}$ was formed, and water and hydrochloric acid were released during the heating. On the DTA curve, there are six visible endothermal effects accompanied by a weight decrease. The first effect (maximum at $125^{\circ} \mathrm{C}$ ) was attributed to the release of four water molecules, which can be seen also from MS and TG curves (Equation (2)).

$$
\text { STEP } 1: 3 \mathrm{Mg}(\mathrm{OH})_{2} \cdot \mathrm{MgCl}_{2} \cdot 8 \mathrm{H}_{2} \mathrm{O} \rightarrow 3 \mathrm{Mg}(\mathrm{OH})_{2} \cdot \mathrm{MgCl}_{2} \cdot 4 \mathrm{H}_{2} \mathrm{O}+4 \mathrm{H}_{2} \mathrm{O}
$$

The second effect (maximum at $155^{\circ} \mathrm{C}$ ) was associated with the release of two water molecules.

$$
\text { STEP } 2: 3 \mathrm{Mg}(\mathrm{OH})_{2} \cdot \mathrm{MgCl}_{2} \cdot 4 \mathrm{H}_{2} \mathrm{O} \rightarrow 3 \mathrm{Mg}(\mathrm{OH})_{2} \cdot \mathrm{MgCl}_{2} \cdot 2 \mathrm{H}_{2} \mathrm{O}+2 \mathrm{H}_{2} \mathrm{O} \text {. }
$$

The third endotherm (maximum at $185^{\circ} \mathrm{C}$ ) was attributed to the release of one water molecule.

$$
\text { STEP } 3: 3 \mathrm{Mg}(\mathrm{OH})_{2} \cdot \mathrm{MgCl}_{2} \cdot 2 \mathrm{H}_{2} \mathrm{O} \rightarrow 3 \mathrm{Mg}(\mathrm{OH})_{2} \cdot \mathrm{MgCl}_{2} \cdot \mathrm{H}_{2} \mathrm{O}+\mathrm{H}_{2} \mathrm{O} \text {. }
$$

He et al. [40] published TG and differential scanning calorimetry (DSC) curves of Phase 5 of MOC. The authors observed that Phase 5 lost five molecules of water of crystallization before $200{ }^{\circ} \mathrm{C}$; i.e., the loss in crystalline water was about two molecules of water lower than that measured for the Phase 3 analyzed in this study. The fourth endothermic effect (maximum at $215^{\circ} \mathrm{C}$ ) was assigned to the release of one water molecule.

$$
\text { STEP } 4: 3 \mathrm{Mg}(\mathrm{OH})_{2} \cdot \mathrm{MgCl}_{2} \cdot \mathrm{H}_{2} \mathrm{O} \rightarrow 3 \mathrm{Mg}(\mathrm{OH})_{2} \cdot \mathrm{MgCl}_{2}+\mathrm{H}_{2} \mathrm{O} \text {. }
$$

In the next step (maximum at $265{ }^{\circ} \mathrm{C}$ ), the loss of one molecule of crystalline water was also identified.

$$
\text { STEP } 5: 3 \mathrm{Mg}(\mathrm{OH})_{2} \cdot \mathrm{MgCl}_{2} \rightarrow 2 \mathrm{Mg}(\mathrm{OH}) \mathrm{Cl}+\mathrm{Mg}(\mathrm{OH})_{2}+\mathrm{MgO}+\mathrm{H}_{2} \mathrm{O} \text {. }
$$

The last endothermic effect (maximum at $455^{\circ} \mathrm{C}$ ) comprised two consequent effects, where one water molecule and two hydrochloric acids were released.

$$
\begin{gathered}
\text { STEP 6 : } \mathrm{Mg}(\mathrm{OH})_{2} \rightarrow \mathrm{MgO}+\mathrm{H}_{2} \mathrm{O} \\
2 \mathrm{Mg}(\mathrm{OH}) \mathrm{Cl} \rightarrow 2 \mathrm{MgO}+2 \mathrm{HCl} .
\end{gathered}
$$

The release of hydrochloric acid from MOC at temperatures around $400{ }^{\circ} \mathrm{C}$ was well documented by Xia et al. [33], and, later, by Dinnebier et al. [43]. However, in the presented test, the mechanism of 
the last step of the decomposition was described differently than reported; e.g., Cole et al. [44] and He et al. [40], who detected that only hydrochloric acid is released. We distinctly proved, using mass spectroscopy, that water was also released in this step [45].

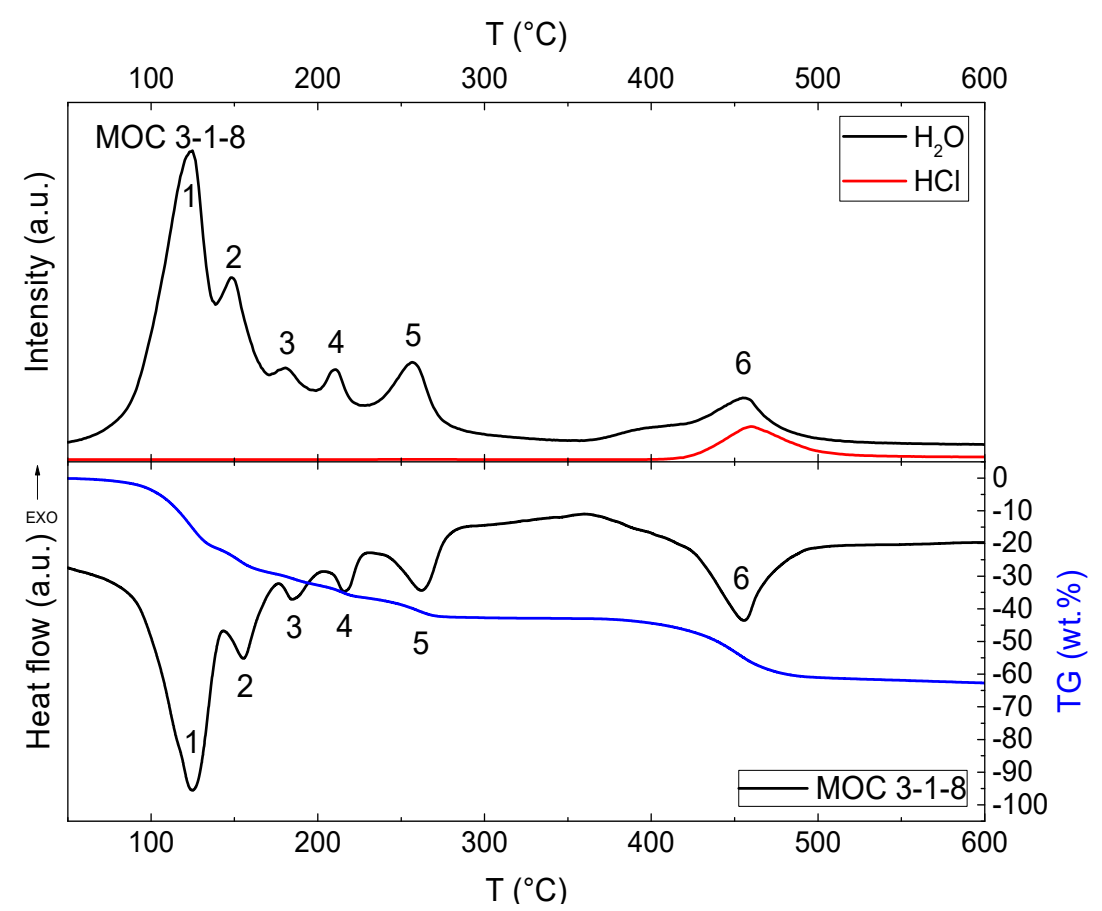

Figure 7. Simultaneous thermal analysis-mass spectroscopy (STA-MS) of MOC 3-1-8 measured in an inner atmosphere: MS signals for water and hydrochloric acid (up) and DTA plus TG signals (down).

\section{Conclusions}

The kinetics of the formation of Phase 3 of MOC and its thermal stability were studied. Although the casted samples were cured freely in a laboratory under an ambient temperature of approximately $(21 \pm 2){ }^{\circ} \mathrm{C}$, the precipitation of the crystalline phase (MOC 3-1-8) started rapidly, and was almost completed after $36 \mathrm{~h}$. It was verified by the measurement of MOC 3-1-8 content that it was at $36 \mathrm{~h}$ $>99 \mathrm{wt} . \%$. The fast formation of the MOC 3-1-8 phase is very promising for the application of this binder in the production of low-energy and low-carbon materials for the construction industry-e.g., in the form of repair cements, floorings, thermal insulation boards, fiber-reinforced MOC plates, and prefabricated elements as sandwich panels, facing slabs, etc. However, one must consider the cost of pure MOC, which is about 1.5 times higher compared to that of PC. On the other hand, in the case of the use of $\mathrm{MgO}$ and $\mathrm{MgCl}_{2}$ of lower purity, the price of $\mathrm{MOC}$ will be significantly reduced. The prices are also affected by the volume of the production of MOC and that of Portland cement, which is much greater and thus readily available and less expensive on the construction market. Furthermore, the availability of raw materials for the calcination of $\mathrm{MgO}$ and $\mathrm{PC}$ affects the price of final commercial products. Nevertheless, the main benefit of the use of MOC cement instead of Portland cement is its low calcination temperature (approximately $700{ }^{\circ} \mathrm{C}$ ) compared to the sintering temperature of $\mathrm{PC}$, which is about $1450{ }^{\circ} \mathrm{C}$. This represents great energy savings, and, thus, a lower carbon footpath. Moreover, as pure MOC phases are too expensive for practical use in the development of construction products, the possible use of industrial by-products as partial substitutes of MOC cements will be the subject of further research. The use of alternative MOC substitutes might greatly reduce the price of MOC cement-based products.

The SEM analysis revealed the dense microstructure of the MOC 3-1-8 phase, composed of interlocked and crosslinked hardened crystalline products. Based on this, the high mechanical resistance of MOC can be anticipated. 
The thermal stability of the examined MOC 3-1-8 is relatively low, as it started to decompose at $125{ }^{\circ} \mathrm{C}$ and was completed at approximately $500{ }^{\circ} \mathrm{C}$, with the total mass loss of $\sim 63 \%$. As the decomposition mechanisms of MOC were identified and clearly characterized, we will focus in future studies on the assessment of the effect of exposure of MOC 3-1-8 to high temperatures on its physical properties, where structural, mechanical, hygric, and thermal parameters will be of particular importance.

Supplementary Materials: The following are available online at http://www.mdpi.com/1996-1944/13/3/767/s1, Figure S1: Diffractograms of raw materials $\mathrm{MgO}$ and $\mathrm{MgCl}_{2} \cdot 6 \mathrm{H}_{2} \mathrm{O}$.

Author Contributions: Conceptualization, O.J., M.P. and D.S.; methodology, O.J., M.P., D.S. and Z.P.; investigation, A.J., M.L., A.-M.L., F.A. and M.P.; data curation, O.J., D.S., M.P. and Z.P., writing-original draft preparation, M.L., A.J., O.J., M.P. and Z.P.; supervision, O.J., D.S., and M.P.; project administration, O.J. and M.P. All authors have read and agreed to the published version of the manuscript.

Funding: This research was funded by the CZECH SCIENCE FOUNDATION, grant number 19-00262S-Reactive magnesia cements-based composites with selected admixtures and additives.

Conflicts of Interest: The authors declare no conflicts of interest.

\section{References}

1. Scrivener, K.L.; John, V.M.; Gartner, E.M. Eco-efficient cements: Potential economically viable solutions for a low- $\mathrm{CO}_{2}$ cement-based materials industry. Cem. Concr. Res. 2018, 114, 2-26. [CrossRef]

2. Medina, J.M.; Sáez del Bosque, I.F.; Frías, M.; Sánchez de Rojas, M.I.; Medina, C. Durability of new blended cements additioned with recycled biomass bottom ash from electric power plants. Constr. Build. Mater. 2019, 225, 429-440. [CrossRef]

3. Bhagatg Singh, G.V.P.; Subramaniam, K.V.L. Production and characterization of low-energy Portland composite cement from post-industrial waste. J. Clean. Prod. 2019, 239. [CrossRef]

4. Souto-Martinez, A.; Arehart, J.H.; Srubar, W.V. Cradle-to-gate $\mathrm{CO}_{2}$ emissions vs. in situ $\mathrm{CO}_{2}$ sequestration of structural concrete elements. Energy Build. 2018, 167, 301-311. [CrossRef]

5. Boesch, M.E.; Koehler, A.; Hellweg, S. Model for cradle-to-gate life cycle assessment of clinker production. Environ. Sci. Technol. 2009, 43, 7578-7583. [CrossRef] [PubMed]

6. Záleská, M.; Pavlíková, M.; Jankovský, O.; Lojka, M.; Pivák, A.; Pavlík, Z. Experimental Analysis of MOC Composite with a Waste-Expanded Polypropylene-Based Aggregate. Materials 2018, 11, 931. [CrossRef] [PubMed]

7. Pavlíková, M.; Zemanová, L.; Pokorný, J.; Záleská, M.; Jankovský, O.; Lojka, M.; Sedmidubský, D.; Pavlík, Z. Valorization of wood chips ash as an eco-friendly mineral admixture in mortar mix design. Waste Manag. 2018, 80, 89-100. [CrossRef] [PubMed]

8. Záleská, M.; Pavlík, Z.; Pavlíková, M.; Scheinherrová, L.; Pokorný, J.; Trník, A.; Svora, P.; Fořt, J.; Jankovský, O.; Suchorab, Z.; et al. Biomass ash-based mineral admixture prepared from municipal sewage sludge and its application in cement composites. Clean Technol. Environ. Policy 2018, 20, 159-171. [CrossRef]

9. Záleská, M.; Pavlíková, M.; Pavlík, Z.; Jankovský, O.; Pokorný, J.; Tydlitát, V.; Svora, P.; Černý, R. Physical and chemical characterization of technogenic pozzolans for the application in blended cements. Constr. Build. Mater. 2018, 160, 106-116.

10. Walling, S.A.; Provis, J.L. Magnesia-Based Cements: A Journey of 150 Years, and Cements for the Future? Chem. Rev. 2016, 116, 4170-4204. [CrossRef] [PubMed]

11. Dehua, D.; Chuanmei, Z. The formation mechanism of the hydrate phases in magnesium oxychloride cement. Cem. Concr. Res. 1999, 29, 1365-1371. [CrossRef]

12. Sorel, S. On a New Magnesium Cement. Comptes Rendus Acad. Sci. 1867, 65, 102-104.

13. Demediuk, T.; Cole, W.F.; Hueber, H.V. Studies on magnesium and calcium oxychlorides. Aust. J. Chem. 1955, 8, 215-233. [CrossRef]

14. Chau, C.K.; Chan, J.; Li, Z. Influences of fly ash on magnesium oxychloride mortar. Cem. Concr. Compos. 2009, 31, 250-254. [CrossRef]

15. Dai, W.; Gong, C.; Lu, L.; Cheng, X. Effect of $\mathrm{MgO}$ on calcination and properties of belite-barium calcium sulphoaluminate cement clinker with $\mathrm{Na}_{2} \mathrm{O}$ and $\mathrm{K}_{2} \mathrm{O}$. Ceram. Silikáty 2018, 62, 121-130. [CrossRef] 
16. Stephan, D.; Dikoundou, S.N.; Raudaschl-Sieber, G. Hydration characteristics and hydration products of tricalcium silicate doped with a combination of $\mathrm{MgO}, \mathrm{Al}_{2} \mathrm{O}_{3}$ and $\mathrm{Fe}_{2} \mathrm{O}_{3}$. Thermochim. Acta 2008, 472, 64-73. [CrossRef]

17. De la Torre, A.G.; De Vera, R.N.; Cuberos, A.J.M.; Aranda, M.A. Crystal structure of low magnesium-content alite: Application to Rietveld quantitative phase analysis. Cem. Concr. Res. 2008, 38, 1261-1269. [CrossRef]

18. Dinnebier, R.E.; Freyer, D.; Bette, S.; Oestreich, M. $9 \mathrm{Mg}(\mathrm{OH})_{2} \cdot \mathrm{MgCl}_{2} \cdot 4 \mathrm{H}_{2} \mathrm{O}$, a High Temperature Phase of the Magnesia Binder System. Inorg. Chem. 2010, 49, 9770-9779. [CrossRef]

19. Dinnebier, R.E.; Oestreich, M.; Bette, S.; Freyer, D. $2 \mathrm{Mg}(\mathrm{OH})_{2} \cdot \mathrm{MgCl}_{2} \cdot 2 \mathrm{H}_{2} \mathrm{O}$ and $2 \mathrm{Mg}(\mathrm{OH})_{2} \cdot \mathrm{MgCl}_{2} \cdot 4 \mathrm{H}_{2} \mathrm{O}$, Two High Temperature Phases of the Magnesia Cement System. Z. Anorg. Allg. Chem. 2012, 638, 628-633. [CrossRef]

20. Tooper, B.; Cartz, L. Structure and Formation of Magnesium Oxychloride Sorel Cements. Nature 1966, 211, 64-66. [CrossRef]

21. Matkovic, B.; Young, J.F. Microstructure of Magnesium Oxychloride Cements. Nature Phys. Sci. 1973, 246, 79-80. [CrossRef]

22. Thompson, H.C. Fireproof Product Using Magnesium Oxychloride Cement. U.S. Patent No. 3,963,849, 15 June 1976.

23. Xu, B.; Ma, H.; Hu, C.; Li, Z. Influence of cenospheres on properties of magnesium oxychloride cement-based composites. Mater. Struct. 2016, 49, 1319-1326. [CrossRef]

24. Misra, A.K.; Mathur, R. Magnesium oxychloride cement concrete. Bull. Mat. Sci. 2007, 30, $239-246$. [CrossRef]

25. Biel, T.D.; Lee, H. Magnesium Oxychloride Cement Concrete with Recycled Tire Rubber. Transp. Res. Rec. 1996, 1561, 6-12. [CrossRef]

26. Ma, J.; Zhao, Y.; Wang, L.; Wang, J. Effect of Magnesium oxychloride Cement on Stabilization/Solidification of Sewage Sludge. Constr. Build. Mater. 2010, 24, 79-83.

27. Li, G.; Yu, Y.; Li, J.; Wang, Y.; Liu, H. Experimental study on urban refuse/magnesium oxychloride cement compound floor tile. Cem. Concr. Res. 2003, 33, 1663-1668. [CrossRef]

28. Karimi, Y.; Monshi, A. Effect of magnesium chloride concentrations on the properties of magnesium oxychloride cement for nano $\mathrm{SiC}$ composite purposes. Ceram. Int. 2011, 37, 2405-2410. [CrossRef]

29. Montle, J.F.; Mayhan, K.G. The role of magnesium oxychloride as a fire-resistive material. Fire Technol. 1974, 10, 201-210. [CrossRef]

30. Li, Z.; Chau, C.K. Influence of molar ratios on properties of magnesium oxychloride cement. Cem. Concr. Res. 2007, 37, 866-870. [CrossRef]

31. Zhou, X.; Li, Z. Light-weight wood-magnesium oxychloride cement composite building products made by extrusion. Constr. Build. Mater. 2012, 27, 382-389. [CrossRef]

32. Weng, R.; Liu, N.; Liu, X.Y.; Yang, X.L. Study of water resistance of magnesium oxychloride cement reinforced by glass fiber. J. Korean Ceram. Soc. 1988, 15, 30-34.

33. Xia, S.; Xing, P.; Gao, S. Studies on the basic compounds of magnesia cement: The thermal behaviour of magnesium oxychlorides. Thermochim. Acta 1991, 183, 349-363. [CrossRef]

34. Xu, B.W.; Ma, H.Y.; Hu, C.L.; Yang, S.Q.; Li, Z.J. Influence of curing regimes on mechanical properties of magnesium oxychloride cement-based composites. Constr. Build. Mater. 2016, 102, 613-619. [CrossRef]

35. Sglavo, V.M.; De Genua, F.; Conci, A.; Ceccato, R.; Cavallini, R. Influence of curing temperature on the evolution of magnesium oxychloride cement. J. Mater. Sci. 2011, 46, 6726-6733. [CrossRef]

36. Liu, Z.; Balonis, M.; Huang, J.; Sha, A.; Sant, G. The influence of composition and temperature on hydrated phase assemblages in magnesium oxychloride cements. J. Amer. Ceram. Soc. 2017, 100, 3246-3261. [CrossRef]

37. Chen, X.; Zhang, T.; Bi, W.; Cheeseman, C. Effect of tartaric acid and phosphoric acid on the water resistance of magnesium oxychloride (MOC) cement. Constr. Build. Mater. 2019, 213, 528-536. [CrossRef]

38. Beaudoin, J.J.; Ramachandran, V.S. Strength development in magnesium oxychloride and other cements. Cem. Concr. Res. 1975, 5, 617-630. [CrossRef]

39. Zhou, Z.; Chen, H.; Li, Z.; Li, H. Simulation of the properties of $\mathrm{MgO}-\mathrm{MgfCl}_{2}-\mathrm{H}_{2} \mathrm{O}$ system by thermodynamic method. Cem. Concr. Res. 2015, 68, 105-111. [CrossRef]

40. He, P.; Poon, C.S.; Tsang, D.C.W. Comparison of glass powder and pulverized fuel ash for improving the water resistance of magnesium oxychloride cement. Cem. Concr. Compos. 2018, 86, 98-109. [CrossRef] 
41. Shi, E.; Ling, Z.; Wang, A. MIR, NIR and Raman Spectra of magnesium chlorides with six hydration degrees-implication for Mars and Europe. J. Raman Spectrosc. 2019, 1-14. [CrossRef]

42. Sugimoto, K.; Dinnebiera, R.E.; Hansonb, J.C. Structures of three dehydration products of bischofite from in situ synchrotron powder diffraction data $\left(\mathrm{MgCl}_{2} \mathrm{nH}_{2} \mathrm{O} ; \mathrm{n}=1,2,4\right)$. Acta Cryst. 2007, B63, 235-242. [CrossRef] [PubMed]

43. Dinnebier, R.E.; Halasz, I.; Freyer, D. The crystal structures of two anhydrous magnesium hydroxychloride phases from in situ synchrotron powder diffraction data. Z. Anorg. Allg. Chem. 2011, 637, 1458-1462. [CrossRef]

44. Cole, W.; Demediuk, T. X-ray, thermal, and dehydration studies on magnesium oxychlorides. Aust. J. Chem. 1955, 8, 234-251. [CrossRef]

45. Lojka, M.; Jiříčková, A.; Lauermannová, A.-M.; Pavlíková, M.; Pavlík, M.; Jankovský, O. Kinetics of formation and thermal stability of $\mathrm{Mg}_{2}(\mathrm{OH})_{3} \mathrm{Cl} \cdot 4 \mathrm{H}_{2} \mathrm{O}$. AIP Conf. Proc. 2019, 2170. [CrossRef]

(C) 2020 by the authors. Licensee MDPI, Basel, Switzerland. This article is an open access article distributed under the terms and conditions of the Creative Commons Attribution (CC BY) license (http://creativecommons.org/licenses/by/4.0/). 